\title{
Content and distribution of conjugated linoleic acid isomers in bovine milk, cheese and butter from Azores
}

\author{
José M. Pestana ${ }^{1,2}$, Susana I.V. Martins ${ }^{1}$, Cristina M.M. Alfaia ${ }^{1}$, \\ Paula A. Lopes ${ }^{1}$, Ana S.H. Costa ${ }^{1}$, Rui J.B. Bessa ${ }^{3}$, Matilde L.F. CAstro ${ }^{2}$, \\ José A.M. Prates ${ }^{1 *}$ \\ ${ }^{1}$ CIISA, Faculdade de Medicina Veterinária, Avenida da Universidade Técnica, \\ Pólo Universitário do Alto da Ajuda, 1300-477 Lisboa, Portugal \\ 2 iMed, Faculdade de Farmácia, Avenida Professor Gama Pinto, 1649-003 Lisboa, Portugal \\ ${ }^{3}$ Unidade de Produção Animal, L-INIA, Instituto Nacional dos Recursos Biológicos, Fonte Boa, \\ 2005-048 Vale de Santarém, Portugal
}

Received 19 June 2008 - Accepted 28 November 2008

\begin{abstract}
Pasture intake is a major factor affecting the content and the distribution of the conjugated linoleic acid (CLA) isomers in bovine milk fat. The aim of this study was to determine the CLA contents and its isomeric distribution in milk, cheese and butter from Azores, a Portuguese archipelago in the Atlantic Ocean. The CLA isomers were analysed using $\mathrm{Ag}^{+}-\mathrm{HPLC}$ with three silver ion columns in series. Butter was the richest product in CLA, with a total of $6.58-7.72 \mathrm{mg} \cdot \mathrm{g}^{-1}$, whereas cheese presented the highest specific CLA content $\left(12.40-14.00 \mathrm{mg} \cdot \mathrm{g}^{-1}\right.$ fat). The CLA isomeric distribution showed a clear predominance of the bioactive cis-9,trans-11 isomer (from $72.26 \%$ to $82.59 \%$ ). The trans-11,cis-13 CLA isomer, a useful indicator of pasture-fed cow's milk, varied from $2.22 \%$ to $3.91 \%$. In conclusion, the Azorean dairy products have a relatively high amount of CLA, especially the cis-9, trans-11 isomer, constituting therefore a good source of these compounds for the human diet.
\end{abstract}

conjugated linoleic acid / milk / cheese / butter / pasture

摘要 - 亚速尔群岛乳及乳制品中共轭亚油酸异构体的含量和分布。牧草是影响牛乳脂肪中 共轭亚油酸 (CLA) 异构体含量和分布的主要因素。本文了研究大西洋葡萄牙所属的 亚速尔群岛地区牛奶、干酪和奶油中共轭亚油酸异构体的含量和分布。用 3 根串联 的银离子柱经 $\mathrm{Ag}^{+}$-高效液相色谱测定乳制品中 CLA 异构体。奶油中总 CLA 的含量最高 $\left(6.58-7.72 \mathrm{mg} \cdot \mathrm{g}^{-1}\right)$, 而干酪中特殊 CLA 的含量最高 $\left(12.40-14.00 \mathrm{mg} \cdot \mathrm{g}^{-1}\right)$ 。具有生物活性的 cis-9, trans-11 异构体 $(72.26 \% \sim 82.59 \%)$ 在 CLA 异构体分布中占有明显的优势。 trans-11, $c i s-13$ 异构体作为牧草饲养奶牛乳脂肪中 CLA 异构体的特征成分, 其含量变化范围 在 $2.22 \% \sim 3.91 \%$ 。因此, 亚速尔群岛乳制品中 CLA, 特别是 cis-9, trans-11 异构体含量非 常高, 是一类营养价值较高的乳制品。

\section{共轭亚油酸 / 牛奶 / 干酪 / 奶油 / 牧草}

Résumé - Teneur et distribution des isomères de l'acide linoléique conjugué (CLA) dans le lait de vache, le fromage et le beurre des Açores. L'ingestion de pâture est le principal facteur qui affecte la concentration et la distribution des isomères de l'acide linoléique conjugué (CLA) de la matière grasse

* Corresponding author (通讯作者): japrates@fmv.utl.pt 
du lait bovin. L'objectif de cette étude était de déterminer la teneur en CLA et la distribution de ses isomères dans le lait, le fromage et le beurre des Açores, un archipel Portugais de l'Océan Atlantique. Les isomères de CLA ont été analysés par $\mathrm{Ag}^{+}$-HPLC, utilisant trois colonnes ioniques argentées, en série. Le beurre était le produit le plus riche en CLA, avec un total de $6,58-7,72 \mathrm{mg} \cdot \mathrm{g}^{-1}$, tandis que le fromage présentait la plus grande teneur spécifique en CLA $\left(12,40-14,00 \mathrm{mg} \cdot \mathrm{g}^{-1}\right.$ matière grasse). La distribution des isomères de CLA a montré une nette prédominance de l'isomère bioactif cis-9, trans11 (de 72,26 à 82,59\%). La teneur en isomère trans-11,cis-13, indicateur de l'ingestion de pâture par les vaches, variait de 2,22 à 3,91\%. En conclusion, les produits laitiers des Açores ont une teneur relativement élevée en CLA, et particulièrement en isomère cis-9, trans-11, constituant ainsi une bonne source de ces composés pour l'alimentation humaine.

acide linoléique conjugué / lait / fromage / beurre / pâture

\section{INTRODUCTION}

Milk and dairy products have always played an important role in human nutrition and, more recently, have also been described as an important source of a variety of relevant biologically-active molecules [19]. Among these compounds, the conjugated positional and geometric isomers of linoleic acid (cis9,cis-12 octadecadienoic acid), commonly known as the conjugated linoleic acid (CLA), have attained a research interest recently. The beneficial effects of CLA on health have been reported in a number of studies using animal models of a variety of human diseases and a range of culture cells (see e.g. [24]). Therefore, it has been suggested that CLA isomers (cis-9,trans-11 and trans-10,cis-12) exhibit important biological activities for the human health that include anticarcinogenic, anti-obesity, antidiabetogenic, anti-atherogenic, immunomodulation and modulation of bone growth [3].

A group of 24 different CLA isomers have been described as occurring naturally in food, especially in ruminant fat [6]. However, in milk and dairy products the main CLA isomer in ruminant fat, cis-9,trans-11 CLA (i.e. rumenic acid), generally comprises about $75-90 \%$ of the total CLA [4]. Variation in the CLA content in meat and in dairy products has been attributed to breed, species, age and individual environmental conditions, such as feeding regime, dietary fatty acids, season and farm management [12]. Nevertheless, diet is believed to be the most significant factor affecting the CLA content in milk fat [4]. Ward et al. [25] also demonstrated that the CLA content of milk increased linearly with an increase in the dietary proportion of pasture fresh grass in the diet.

The Azores archipelago, located in the Atlantic Ocean, is an important dairy region of Portugal, that is being responsible for $27 \%$ of the total milk production of the country. Azores archipelago is deeply influenced by the Gulf Stream, with no frost below elevations of $500 \mathrm{~m}$, and an average temperature of $15{ }^{\circ} \mathrm{C}$ in the winter and $22{ }^{\circ} \mathrm{C}$ in the summer [15]. These islands present unique edapho-climatic features that allow grazing throughout the year, and thus provide a diet based on fresh grass. The objective of this study was to analyse the CLA content and its isomeric distribution in Azorean bovine milk, cheese and butter from two different commercial brands. The data will be used to compare the CLA composition of Azorean dairy products with similar products originated from other regions.

\section{MATERIALS AND METHODS}

\subsection{Reagents and standard solutions}

All reagents were of analytical and liquid chromatographical grade. Commercial 
standards of individual CLA isomers (cis-9, cis-11, trans-10,cis-12, cis-9,trans-11 and trans-9,trans-11) as methyl esters were purchased from Matreya Inc. (Pleasant Gap, PA, USA). Additional standards of individual (trans-8,cis-10 and cis-11,trans-13) and mixtures (cis/trans, trans/cis and trans/trans from positions 7,9 to 12,14) of CLA isomers were prepared as methyl esters according to the procedure described by Destaillats and Angers [8].

\subsection{Milk and dairy samples}

Ten samples of each of the two most important commercial brands of ultrapasteurised half-skimmed milk, flamengo cheese and butter were purchased from a regular supermarket between September 2004 and February 2005. All samples were obtained from different lots of the most consumed commercial brands in Portugal of each dairy product under analysis. Milk was kept frozen at $-21^{\circ} \mathrm{C}$ until the analysis was performed. Cheese and butter samples were homogenised using a food processor for $3 \times 5$ s (Moulinex type 320, Ecully Cedex, France), vacuum packed and stored at $-21{ }^{\circ} \mathrm{C}$, for a period no longer than 3 months.

\subsection{Lipid extraction and methylation}

Lipid extraction and fatty acid transesterification of milk and cheese were performed using the methodology described in ES ISO 5508 [9]. Briefly, milk samples $(20 \mathrm{~mL})$ were mixed with $5 \mathrm{~mL}$ of ammonia solution and $10 \mathrm{~mL}$ of ethanol. Lipids were extracted three times with $25 \mathrm{~mL}$ of diethyl ether/petroleum ether mixture $(1: 1 \mathrm{v} / \mathrm{v})$. The ethereal extracts (ether/lipid extract) were collected to a glass balloon and concentrated, using a rotoevaporator at $30{ }^{\circ} \mathrm{C}$, to a final volume of $1-3 \mathrm{~mL}$. The extracts were dried at $90{ }^{\circ} \mathrm{C}$ for $1 \mathrm{~h}$ and the total fat was determined gravimetrically. Then, $4 \mathrm{~mL}$ of isopentane was added to the glass balloon to drag the fat that was transferred to a screw Teflon-lined cap tube. Fat cheese content was determined similarly to milk after weighting $1 \mathrm{~g}$ acidification with chloridric acid instead of ammonia solution. Fatty acid transesterification was performed by adding $2 \mathrm{~mL}$ of methanolic potassium hydroxide and well shaken for $20 \mathrm{~s}$. The upper layer was removed to a vial for injection on the high-performance liquid chromatography (HPLC) system.

Fat extraction in butter and its methylation were carried out according to NP2283 [18]. The butter $(2.5 \mathrm{~g})$ was dried at $102{ }^{\circ} \mathrm{C}$ overnight to remove the moisture content. The fat content was determined based on the difference between the dried weight and the fat portion that was dissolved in the petroleum ether $\left(25 \mathrm{~m} \cdot \mathrm{L}^{-1}\right)$. For butter fat extraction, $1 \mathrm{~g}$ was weighed into a screw Teflon-lined cap tube, and $10 \mathrm{~m} \cdot \mathrm{L}^{-1}$ of isopentane was added to dissolve the lipid fraction. Fatty acid methyl esters were obtained similar to those of milk and cheese.

\subsubsection{Determination of individual CLA isomers}

The methyl esters of CLA isomers were individually separated by three silver ion columns in series (ChromSpher 5 Lipids, $250 \mathrm{~mm} \times 4.6 \mathrm{~mm}$ i.d., $5 \mu \mathrm{m}$ particle size, Chrompack, Bridgewater, NJ, USA), using an HPLC system $\left(\mathrm{Ag}^{+}\right.$-HPLC) (Agilent 1100 Series, Agilent Technologies Inc., Palo Alto, CA, USA), as reported previously by Alfaia et al. [1]. Briefly, the mobile phase was $0.1 \%$ acetonitrile in $n$-hexane, at a flow rate of $1 \mathrm{~mL} \cdot \mathrm{min}^{-1}$; the diode array detector was adjusted to $233 \mathrm{~nm}$, and the injection volumes were $30 \mu \mathrm{L}$ for milk and $10 \mu \mathrm{L}$ for cheese and butter. The identification of the individual CLA isomers was achieved by comparing their retention times with commercial and prepared standards. 
Total and individual contents of CLA isomers in dairy products were determined based on the external standard technique, using cis-9,cis-11, trans-10,cis-12, cis-9, trans-11 and trans-9,trans-11 as representatives of each geometric group of CLA isomers, and on the method of area normalisation, from standard curves for peak area vs. CLA isomer concentration. The CLA isomers were expressed in gravimetric contents $\left(\mathrm{mg} \cdot \mathrm{g}^{-1}\right.$ or $\mathrm{mg} \cdot \mathrm{mL}^{-1}$ product and $\mathrm{mg} \cdot \mathrm{g}^{-1}$ fat) or as a percentage of the sum of the identified CLA isomers (\% total CLA).

\subsection{Statistical analysis}

Statistical analysis of the results was performed using Statistical Analysis Software [23]. Analysis of variance was used to determine the statistical differences between commercial brands, within each type of product and among types of products. Results were expressed as mean and standard error of mean. A $P<0.05$ was considered as a significant difference.

\section{RESULTS AND DISCUSSION}

\subsection{CLA contents}

Table I shows the CLA contents and its isomeric distribution in the analysed Azorean milk and dairy products, commercially available in the mainland Portugal, using the $\mathrm{Ag}^{+}$-HPLC methodology.

As expected, the data showed that butter is the richest product in total fat and total CLA $(P<0.05)$, exhibiting $81.37-81.45 \%$ and $6.58-7.72 \mathrm{mg} \cdot \mathrm{g}^{-1}$ product, respectively, in contrast to milk, which has $1.23-1.35 \%$ and $0.01-0.02 \mathrm{mg} \cdot \mathrm{mL}^{-1}$ product, respectively. No differences $(P>0.05)$ were observed between commercial brands, within each type of product, neither for total fat nor for total CLA content. The values described in this study for total CLA are higher than those reported for milk, cheese and butter in the samples derived from the milk produced in farms located in the mainland Portugal, which were of $0.11,1.09$ and $2.64 \mathrm{mg} \cdot \mathrm{g}^{-1}$ product, respectively [17].

Regarding the specific CLA content, cheese displayed the highest values $\left(12.40-14.00 \mathrm{mg} \cdot \mathrm{g}^{-1} \mathrm{fat}\right)$, and was significantly higher than the CLA concentration in butter (8.09-9.48 mg.g ${ }^{-1}$ fat). The commercial brand did not significantly affect $(P>0.05)$ the specific CLA content. The specific CLA content in milk was 10.60 $11.41 \mathrm{mg} \cdot \mathrm{g}^{-1}$ fat, which is slightly lower than a recently published value for Azorean UHT milk $\left(13.3 \mathrm{mg} \cdot \mathrm{g}^{-1}\right.$ total fatty acids for cis-9,trans-11 isomer) [15]. This slight difference may be due to regional variations, as well as due to differences in the CLA quantification methods used in the two studies ( $\mathrm{Ag}^{+}$-HPLC vs. GC). Relatively high amounts of CLA (12 mg.g ${ }^{-1}$ fat) were also described, by Precht and Molkentin [20], for German milks. However, the specific contents of CLA described here for Azorean milks are higher than those reported for the mainland Portuguese [17] and Italian [2] milks.

The Azorean cheeses analysed in this work contain higher specific CLA contents than the mainland Portuguese [17] and Spanish [16] cheeses. The specific CLA content in German cheeses ranged from 4.0 to $17.0 \mathrm{mg} \cdot \mathrm{g}^{-1}$ fat [10], whereas the specific CLA of French cheeses varied between 5.3 and $15.8 \mathrm{mg} \cdot \mathrm{g}^{-1}$ fat [14].

The values of specific CLA content found in this study for butter (8.09$9.48 \mathrm{mg} \cdot \mathrm{g}^{-1}$ fat) are lower than those obtained for German, Italian and Netherlanders butters [21], but higher than those described for the mainland Portuguese butters [17].

\subsection{CLA isomeric distribution}

The CLA isomeric profile of Azorean dairy products suggests a clear predominance 
Table I. Values of total fat $(\% \mathrm{w} / \mathrm{w})$, total $\left(\mathrm{mg} \cdot \mathrm{mL}^{-1}\right.$ or $\mathrm{mg} \cdot \mathrm{g}^{-1}$ product) and specific $\left(\mathrm{mg} \cdot \mathrm{g}^{-1}\right.$ fat) CLA contents, and its isomeric distribution (\% of identified CLA isomers) in Azorean bovine milk, cheese and butter from several commercial brands $(n=10$ for each brand of milk, cheese and butter).

\begin{tabular}{|c|c|c|c|c|c|c|c|c|c|c|c|c|c|}
\hline \multirow{2}{*}{$\begin{array}{l}\text { Total fat } \\
\text { and CLA } \\
\text { content }\end{array}$} & \multicolumn{2}{|c|}{ Milk (M) } & \multirow[b]{2}{*}{ SEM } & \multicolumn{2}{|c|}{ Cheese (C) } & \multirow[b]{2}{*}{ SEM } & \multicolumn{2}{|c|}{ Butter (B) } & \multirow[b]{2}{*}{ SEM } & \multirow[t]{2}{*}{ Product effect } & \multicolumn{3}{|c|}{ Brand effect } \\
\hline & $\begin{array}{c}\text { Nova } \\
\text { Açores }\end{array}$ & $\begin{array}{c}\text { Terra } \\
\text { Nostra }\end{array}$ & & $\begin{array}{c}\text { Terra } \\
\text { Nostra }\end{array}$ & Loreto & & Loreto & $\begin{array}{c}\text { Nova } \\
\text { Açores }\end{array}$ & & & M & $\mathrm{C}$ & $\mathrm{B}$ \\
\hline Total fat & 1.23 & 1.35 & 0.082 & 21.74 & 21.76 & 0.475 & 81.37 & 81.45 & 0.164 & $\mathrm{M}<\mathrm{C}<\mathrm{B}$ & ns & ns & ns \\
\hline Total CLA & 0.01 & 0.02 & 0.002 & 2.99 & 2.68 & 0.293 & 6.58 & 7.72 & 0.418 & $\mathrm{M}<\mathrm{C}<\mathrm{B}$ & ns & ns & ns \\
\hline Specific CLA & 10.60 & 11.41 & 1.988 & 14.00 & 12.40 & 1.383 & 8.09 & 9.48 & 0.515 & $\mathrm{~B}=\mathrm{M}, \mathrm{M}=\mathrm{C}, \mathrm{B}<\mathrm{C}$ & ns & ns & ns \\
\hline \multicolumn{14}{|l|}{ CLA isomers } \\
\hline trans-12,trans-14 & 1.89 & 1.30 & 0.098 & 1.72 & 1.47 & 0.061 & 1.38 & 1.58 & 0.042 & $\mathrm{M}=\mathrm{C}=\mathrm{B}$ & $* * *$ & $* *$ & $* *$ \\
\hline trans -11, trans -13 & 2.93 & 2.73 & 0.114 & 3.03 & 2.70 & 0.099 & 2.79 & 3.03 & 0.050 & $\mathrm{M}=\mathrm{C}=\mathrm{B}$ & ns & $*$ & $* *$ \\
\hline trans -10, trans -12 & 1.11 & 0.98 & 0.054 & 0.92 & 0.90 & 0.049 & 0.82 & 0.83 & 0.037 & $\mathrm{~B}=\mathrm{C}<\mathrm{M}$ & ns & ns & ns \\
\hline trans -9, trans -11 & 2.98 & 3.81 & 0.859 & 1.67 & 1.75 & 0.110 & 1.12 & 1.35 & 0.058 & $\mathrm{~B}=\mathrm{C}<\mathrm{M}$ & ns & ns & $*$ \\
\hline trans -8, trans -10 & 0.62 & 0.53 & 0.056 & 0.67 & 0.69 & 0.055 & 0.44 & 0.48 & 0.025 & $\mathrm{~B}<\mathrm{M}<\mathrm{C}$ & ns & ns & ns \\
\hline trans -7, trans -9 & 1.10 & 0.82 & 0.139 & 0.72 & 0.60 & 0.032 & 0.62 & 0.59 & 0.043 & $\mathrm{C}=\mathrm{B}<\mathrm{M}$ & ns & $*$ & ns \\
\hline trans -6, trans -8 & 0.42 & 0.21 & 0.075 & 0.22 & 0.15 & 0.027 & 0.18 & 0.15 & 0.016 & $\mathrm{C}=\mathrm{B}<\mathrm{M}$ & ns & ns & ns \\
\hline Total trans/trans & 11.05 & 10.38 & 1.086 & 8.95 & 8.26 & 0.329 & 7.35 & 8.01 & 0.169 & $\mathrm{C}=\mathrm{B}<\mathrm{M}$ & ns & ns & $*$ \\
\hline cis/trans-12-14 & ND & ND & ND & 0.75 & 0.63 & 0.045 & 0.62 & 0.75 & 0.027 & $\mathrm{M}<\mathrm{C}=\mathrm{B}$ & ns & ns & $* *$ \\
\hline trans -11, cis $-13^{\mathrm{a}}$ & 2.22 & 2.30 & 0.087 & 2.37 & 3.91 & 0.546 & 3.05 & 2.45 & 0.642 & $\mathrm{M}=\mathrm{C}=\mathrm{B}$ & ns & ns & ns \\
\hline cis-11,trans-13 & 0.50 & 0.20 & 0.094 & - & - & - & ND & 0.44 & 0.059 & $\mathrm{C}<\mathrm{B}=\mathrm{M}$ & $*$ & ns & $* * *$ \\
\hline trans -10, cis -12 & ND & ND & ND & ND & ND & ND & ND & ND & ND & - & - & - & - \\
\hline cis-9,trans-11 & 79.30 & 79.88 & 1.177 & 82.59 & 72.26 & 0.100 & 82.11 & 81.42 & 0.747 & $\mathrm{C}=\mathrm{M}, \mathrm{M}=\mathrm{B}, \mathrm{C}<\mathrm{B}$ & ns & $* * *$ & ns \\
\hline trans $-7, c i s-9^{\mathrm{b}}$ & 6.94 & 7.25 & 0.709 & 5.34 & 14.95 & 0.958 & 6.88 & 6.94 & 0.486 & $\mathrm{~B}=\mathrm{M}<\mathrm{C}$ & ns & $* * *$ & ns \\
\hline Total cis/trans & 88.96 & 89.63 & 1.086 & 91.05 & 91.75 & 0.329 & 92.66 & 92.00 & 0.169 & $\mathrm{M}<\mathrm{C}=\mathrm{B}$ & ns & ns & $*$ \\
\hline Total cis/cis & ND & ND & ND & ND & ND & ND & ND & ND & ND & - & - & - & - \\
\hline
\end{tabular}

ns, not significant; * $P<0.05 ; * * P<0.01 ; * * * P<0.001$; ND, not detected; SEM, standard error of mean.

${ }^{a}$ In cheese samples, the CLA isomer co-eluted with minor amounts of the cis-11,trans-13 isomer.

b The CLA isomer co-eluted with minor amounts of the trans-8,cis-10 isomer. 
of the bioactive cis-9,trans-11 isomer (72.26-82.59\%), followed by trans-7,cis-9 $(5.34-14.95 \%)$ and trans-11,trans-13 $(2.93-3.03 \%)$ isomers, as represented in Table I. Interestingly, the other bioactive CLA isomer, trans-10,cis-12, was not detected in any analysed samples. The major CLA isomer, cis-9,trans-11, is produced in the rumen during the microbial biohydrogenation of dietary linoleic acid and endogenously in the tissues through $\Delta 9$ desaturation of trans-11 C18:1 [11]. Wahle et al. [24] reported that a total of $70 \%$ of rumenic acid in milk fat is derived from this last process. In addition, Corl et al. [5] demonstrated that trans-7,cis-9 isomer in milk fat is originated almost exclusively via endogenous synthesis by $\Delta 9$-desaturation with ruminally derived trans-7 C18:1. Finally, Kraft et al. [13] hypothesised that $\alpha$-linolenic acid, the major fatty acid of pasture, is the indirect precursor of the trans-11,cis-13 CLA isomer.

Milk, cheese and butter showed relatively high percentages of trans-11,cis-13, trans-11,trans-13 and trans-12,trans-14 CLA isomers, which have been suggested to constitute sensitive grass intake indicators [7]. Luna et al. [16] reported similar percentages for trans-12,trans-14 and trans11,trans-13 CLA isomers in cheese and milk. The values given in this work for these grass-sensitive CLA isomers are higher than those reported for the mainland Portugal, which may reflect better quality of Azorean pastures in relation to the mainland Portugal [15]. Rickert et al. [22] reported lower total trans/trans CLA isomers in cheese compared with the values described in this study. In addition, total trans/trans and cis/trans (cis/trans and trans/cis) CLA isomers in cheese were similar to those reported by Luna et al. [16]. Finally, no cis/cis CLA isomer was detected in the various samples analysed in this study.

The relative percentages of trans -12 , trans-14, trans-11,trans-13 and trans-11, cis-13 CLA isomers did not show significant differences among the several types of products analysed. This fact suggests that the relative contents of these CLA isomers remain constant from milk, the raw material, to butter and cheese. Comparing with cheese and butter, milk is the product with the highest percentage of total trans/trans CLA isomers, in particular trans-10,trans12, trans-9,trans-11, trans-7,trans-9 and trans-6,trans-8 isomers. Among milk and dairy products, the highest percentages of CLA isomers were the cis-9,trans-11 in butter and the trans-7,cis-9 isomer in cheese.

The CLA isomeric distribution depicted differences between commercial brands within the same type of product. For milk, Nova Açores brand was the richest in trans-12,trans-14 and cis-11,trans-13 CLA isomers. Regarding cheese, trans-12,trans14, trans-11,trans-13, trans-7,trans-9, cis9,trans-11 and trans-7,cis-9 CLA isomers present in Terra Nostra samples were significantly higher than those in Loreto samples, except for trans-7,cis-9 isomer. In butter, trans-12,trans-14, trans-11,trans-13, trans9,trans-11, cis/trans-12,14 and CLA cis11 ,trans-13 were affected by commercial brand. Nova Açores was the richest brand in these isomers.

\section{CONCLUSION}

Azorean bovine milk and dairy products are important sources of CLA, when compared with similar products originated from other regions, including the mainland Portugal. This fact likely results from the good quality of pastures and grazing conditions of Azores archipelago, which improve CLA content in milk and have similar subsequent effects on cheese and butter. As expected, butter is the most interesting dairy product for the consumer, containing relatively high contents of total CLA and its cis-9,trans-11 isomer, for all the analysed commercial brands. Although there were no important differences in CLA contents between the Azorean brands for the same type of product, 
the CLA isomeric distribution showed few differences between the brands.

Acknowledgements: This work was supported by grants POCTI/CVT/2002/44750 (FCT, MCTES) and Mestrado em Controlo da Qualidade e Toxicologia dos Alimentos (FF, UL). The authors thank Olga M.C. Moreira for the help in preparing the abstract in French.

\section{REFERENCES}

[1] Alfaia C., Quaresma M., Castro M., Martins S., Portugal A., Fontes C., Bessa R., Prates J., Fatty acid composition, including isomeric profile of conjugated linoleic acid, and cholesterol in Mertolenga-PDO beef, J. Sci. Food Agric. 86 (2006) 2196-2205.

[2] Banni S., Carta G., Contini M.S., Angioni E., Deiana M., Dessi M.A., Melis M.P., Corongiu F.P., Characterization of conjugated diene fatty acids in milk and dairy products, and lamb tissues, J. Nutr. Biochem. 7 (1996) 150-155.

[3] Belury M.A., Dietary conjugated linoleic acid in health: physiological effects and mechanisms of action, Annu. Rev. Nutr. 22 (2002) 505-531.

[4] Collomb M., Schimd A., Sieber R., Wechsler D., Ryhänen E., Conjugated linoleic acid in milk fat: variation and physiological effects, Int. Dairy J. 16 (2006) 1347-1361.

[5] Corl B.A., Baumgard L.H., Griinari J.M., Delmonte P., Morehouse K.M., Yurawecz M.P., Trans-7,cis-9 CLA is synthesized endogenously by $\Delta 9$-desaturase in dairy cows, Lipids 37 (2002) 681-688.

[6] Cruz-Hernandez C., Deng Z., Zhou J., Hill A.R., Yurawecz M.P., Delmonte P., Mossoba M.M., Dugan M.E., Kramer J.K., Methods for analysis of conjugated linoleic acids and trans-18:1 isomers in dairy fats by using a combination of gas chromatography, silver-ion thin-layer chromatography/gas chromatography, and silver-ion liquid chromatography, J. AOAC Int. 87 (2004) 545-562.

[7] Dannenberger D., Nuernberg K., Nuernberg G., Scollan N., Steinhart H., Ender K., Effect of pasture vs. concentrate diet on CLA isomer distribution in different tissue lipids of beef cattle, Lipids 40 (2005) 589-598.
[8] Destaillats F., Angers P., Directed sequential synthesis of conjugated linoleic acid isomers from d7,9 to d12,14, Eur. J. Lipid Sci. Technol. 105 (2003) 3-8.

[9] ES ISO 5508, Animal and Vegetable Fats and Oils - Analysis by Gas Chromatography of Methyl Esters of Fatty Acids, European Standard ISO 5508, European Committee for Standardization, Brussels, Belgium, 1990.

[10] Fritsche J., Steinhart H., Analysis, occurrence, and physiological properties of trans fatty acid (TFA) with particular emphasis on conjugated linoleic acid isomers (CLA): a review, Fett/Lipid 100 (1998) 190-210.

[11] Griinari J.M., Chouinard P.Y., Bauman D.E., Trans fatty acid hypothesis of milk fat depression revised, in: Proceedings of the Cornell Nutrition Conference for Feed Manufacturers, Cornell University, Ithaca, NY, USA, 1997, pp. 28-216.

[12] Jahreis G., Fritsche J., Kraft J., Speciesdependent, seasonal, and dietary variation of conjugated linoleic acid in milk, in: Yurawecz M.P., Mossoba M.M., Kramer J.K.G., Pariza M.W., Nelson G.J. (Eds.), Advances in Conjugated Linoleic Acid Research, vol. 1, AOCS Press, Champaign, IL, USA, 1999, pp. 215-225.

[13] Kraft J., Collomb M., Möckel P., Sieber R., Jahreis G., Differences in CLA isomer distribution of cow's milk, Lipids 38 (2003) 657-664.

[14] Lavillonnière F., Martin J.C., Bougnoux P., Sébédio J.L., Analysis of conjugated linoleic acid isomers and content in French cheeses, J. Am. Oil Chem. Soc. 75 (1998) 343-352.

[15] Leite J., Lima E., Baptista J., Azorean bovine milk conjugated linoleic acid. Effect of green pasture diet, storage and processing temperature, Lait 87 (2007) 167-179.

[16] Luna P., De la Fuente M.A., Juárez M., Conjugated linoleic acid in processed cheeses during the manufacturing stages, J. Agric. Food Chem. 53 (2005) 2690-2695.

[17] Martins S.V., Lopes P.A., Alfaia C.M., Ribeiro V.S., Guerreiro T.V., Fontes C., Castro M.F., Soveral G., Prates J.A., Contents of conjugated linoleic acid in ruminant - derived foods and estimation of their contribution to daily intake in Portugal, $\mathrm{Br}$. J. Nutr. 98 (2007) 1206-1213.

[18] NP 2283, Manteiga - Determinação dos teores de água, de resíduo seco isento de 
matéria gorda e de matéria gorda, Direcção Geral da Qualidade, Lisboa, Portugal, 1984.

[19] Prates J.A., Mateus C., Functional foods from animal sources and their physiologically active components, Rev. Med. Vet.Toulouse 153 (2002) 155-160.

[20] Precht D., Molkentin J., Effect of feeding on conjugated cis $\Delta 9$, trans $\Delta 11$-octadecadienoic acid and other isomers of linoleic acid in bovine milk fats, Nahrung 41 (1997) 330-335.

[21] Precht D., Molkentin J., Frequency distribution of conjugated linoleic acid and trans fatty acid content in European bovine milk fats, Milchwissenschaft 55 (2000) 687-691.

[22] Rickert R., Steinhart H., Fristche J., Sehat J., Yurawecz M.P., Mossoba M.M., Roach J.A.G., Eulitz K., Ku Y., Kramer J.K.G.,
Enhanced resolution of conjugated linoleic acid isomers by tandem-column silverion high performance liquid chromatography, J. High Resolut. Chrom. 22 (1999) 144-148.

[23] Statistical Analysis System, SAS/STAT 9.1 User's Guide, SAS Institute Inc., Cary, NC, USA, 2004.

[24] Wahle K.W., Heys S.D., Rotondo D., Conjugated linoleic acids: are they beneficial or detrimental to health?, Prog. Lipid Res. 43 (2004) 553-587.

[25] Ward A.T., Wittenberg K.M., Froebe H.M., Przybylski R., Malcolmson L., Fresh forage and solin supplementation on conjugated linoleic acid levels in plasma and milk, J. Dairy Sci. 86 (2003) 1742-1750. 